\title{
Simulation Study of Past Climate Change Effect on Chickpea Phenology at Different Sowing Dates in Gorgan, Iran \\ M. Gholipoor* and S. Shahsavani
}

Faculty members of Agriculture College, Shahrood university of Technology

* corresponding author: Dr. Manouchehr Gholipoor, Department of Agronomy and Plant Breeding, Shahrood University of Technology, P.O. Box 36155-316, Shahrood, Iran.

Email: manouchehrg@excite.com

\begin{abstract}
The evaluation of past climate change is needed for selecting appropriate adapting strategy for future. This simulation study was mainly aimed to find the probable difference between sowing dates for response of four chickpea cultivars to past climate change. Firstly, the model CYRUS was recoded in QBASIC programming. Then phenology of cultivars Jam, Hashem, Arman and Beauvanij, seeded at day of year 50, 70 and 90, was evaluated during years 1961 to 2003 in Gorgan, Iran. The changes in some climatic variables were also studied. Results revealed that the solar radiation has been decreased for month December. Although the value of maximum temperature appeared to be the same across years 1961 to 2003 for all months, that of minimum temperature tended to show increasing trend for May and August. The increase in number of days with temperature higher than $35{ }^{\circ} \mathrm{C}$ was considerable for April and October, but negligible for other months. The warming of night temperature was significant only for May and August. It found about $34 \mathrm{~mm}$ per 43 years decrease in monthly rainfall for March. The rate of increase in number of days with rainfall was 0.0737 day year ${ }^{-1}$ for December. Nearly similar situation was found for number of days with rainfall lower than and/or equal to $10 \mathrm{~mm}$. The change in number of days with rainfall higher than $10 \mathrm{~mm}$ and lower and/or equal to $30 \mathrm{~mm}$ was in decreasing manner (March, October and December). The length of time from sowing to emergence appeared to be constant across past years. The advance in flowering (R1) was true only for cultivar Jam seeded at day of year 70. The length of period from R1 to pod initiation (R3) has been diminished for sowing at day of year 70 (Jam and Arman). Only cultivar Hashem seeded at day of year 90 tended to have decreasing trend for length of period between R3 and pod filling. It found one day (per 43 years) decreases from pod yellowing to maturity for cultivar Beauvanij seeded at day of year 70. Based on these findings, and on the fact that future climate change is predicted using past changes, it seems that the adaptation strategies for future, including agronomy and/or breeding programs, may be not the same for different sowing dates of chickpea.
\end{abstract}

Key words: Phenology; chickpea; climate change; CYRUS; sowing date

\section{INTRODUCTION}

There has been considerable concern in recent years about climatic changes caused by human activities and their effects on agriculture (Olfert and Weiss, 2006). Surface climate is always changing, but at the beginning of industrial revolution these changes have been more noticeable due to interference of human beings activity (Cutforth et al., 1999). Studies of climate change impacts on agriculture initially 
focused on rising $\mathrm{CO}_{2}$ levels (Curry et al., 1990). Many researchers, including Pielke et al. (2002) reported that changes in temperature, radiation and precipitation need to be studied in order to evaluate the impact of climate change, beyond the $\mathrm{CO}_{2}$ increase, on crops.

Although, there is general agreement for global warming, the rate of increase in temperature has been different across the seasons and various regions. For example, the reports for Australia indicate that during the period between 1910 and 2000, average temperature has been increased by $0.76{ }^{\circ} \mathrm{C}$ (McInnes et al., 2002). In Iran, results regarding Kermanshah showed that except for January, February and March, the increase in temperature is considerable for all other months, especially June (Gholipoor et al., 2006a). Lu et al. (2006) reported that the increasing trend of temperature has been most considerable in the winter and early spring.

Temperature changes can affect crop productivity. Higher temperatures may increase plant carboxilation and stimulate higher photosynthesis, respiration, and transpiration rates. Meanwhile, flowering may also be partially triggered by higher temperatures, while low temperatures may reduce energy use and increased sugar storage (Fiscus et al., 1997). Reddy et al. (2002) concluded that the rates of plant growth and development would continue to increase in the southern U.S. because of enhanced metabolic rates at higher temperatures, combined with increased carbon availability. Changes in temperature can also affect air vapor pressure deficits, thus impacting the water use in agricultural landscapes (Kirschbaum, 2004). This coupling affects transpiration and can cause significant shifts in temperature and water loss. These feedbacks contribute to regional changes in precipitation and cloudiness, leading to changes in radiation (Pielke et al., 2002).

The radiation has an important role in photosynthesis and crop productivity. There are more evidences for decreasing trend in solar radiation. For instance, Stanhill and Moreshet (1992) after analyzing data of 45 actinometrical stations for the years 1958, 1965, 1975, and 1985 indeed found a statistically significant worldwide decrease of global solar radiation averaging 5.3\%. The decline was largest between 45 and $30^{\circ} \mathrm{N}$. Regional declines have been also reported for the western as well as eastern sections of the former Soviet Union (Abakumova et al., 1996).

It is globally accepted that precipitation is a leading factor affecting, especially, rainfed crops yield (Izaurralde et al., 2003). There are conflicting reports for change in precipitation during last century in different parts of the world. For example, in long-term mean precipitation, a decreasing trend of about $4.1 \mathrm{~mm} / \mathrm{month} / 100$ years has been reported in boreal Asia. The largest and most statistically significant change has been a decline in rainfall in the winter-rainfall-dominated region of the far southwest of western Australia, where during the period of 1910-1995, winter (June-July-August) rainfall declined by 25\%, mainly during the 1960s and 1970s (Smith et al., 2000). In Central America, for much of the period from the early 1940s to 1995, western Mexico has experienced an increasingly erratic monsoonal rainfall 
(Douglas and Englehart, 1999). Annual precipitation trends in past century are characterized essentially by enhanced precipitation in the northern half of Europe, with increases ranging from 10 to close 50\% (Dore, 2005).

Generally, most studies are on fruit trees or trees and there are limited information on crop plant (See references in Gholipoor et al. (2006b) for more detail); there is one published report regarding effect of past climate change on chickpea phenology (in Kermanshah, Iran) which has been based only on one sowing date (Gholipoor et al., 2006b).This simulation study was mainly aimed to find the probable difference between sowing dates for response of four chickpea cultivars to past climate change; the changes in some climatic variables were also considered to be evaluated. The result of this study may be useful for selecting appropriate adapting strategy for sustaining the chickpea yield in future.

\section{MATERIALS and METHODS}

The weather data from 1961 to 2003 for Gorgan ( $36^{\circ} 85^{\prime}$ N, $54^{\circ} 27^{\prime}$ E and $100 \mathrm{~m}$ asl) Iran, was used for calculating the probable change in monthly values of some climatic variables. Data set contained daily values for sunshine hours, maximum temperature, minimum temperature and rainfall. Solar radiation data were calculated from sunshine hours and extraterrestrial solar radiation as outlined by Doorenbos and Pruitt (1977). A simple QBASIC program was written for calculating monthly values of some climatic variables including solar radiation, maximum and minimum temperatures, number of days with temperature greater than $35^{\circ} \mathrm{C}$, number of days with temperature lower than $0{ }^{\circ} \mathrm{C}$, night temperature, day temperature, rainfall, number of days with rainfall, number of days with rainfall lower than and/or equal to $10 \mathrm{~mm}$, number of days with rainfall greater than 10 and lower than and/or equal to $30 \mathrm{~mm}$, and number of days with rainfall greater than $30 \mathrm{~mm}$. For calculating the rate of change in each climatic variable for period 1961-2003, the parameters "a" (intercept) and "b" (slope) in linear regression equation (Y=a+bX) were calculated, using the Statistical Analysis System (SAS Institute, 1989). The value of "b" was considered as rate of change.

We used the model CYRUS (see following paragraphs) for investigating the phenological response of chickpea to past climate change in Gorgan, Iran. Firstly, it was recoded in QBASIC programming language, and then run for above named weather data set. The cultivars were Hashem, Jam, Beauvanij and Arman, and the sowing dates were 50,70 and 90 day of year. In each year, the phenological phases including periods from sowing to emergence (sowing-E), from emergence to flowering (E-R1), from flowering to pod initiation (R1-R3), from pod initiation to pod filling (R3-R5), from pod filling to pod yellowing (R5-R7) and from pod yellowing to physiological maturity (R7-R8) were calculated. Like climatic variables, the value of "b" considered as rate of change in each phenological phase. 
The model CYRUS was initially designed in 1999 by Soltani et al. (1999). Then it was developed for seedling emergence (Soltani et al., 2006e), for leaf expansion and senescence (Soltani et al., 2006d), for response of leaf expansion and transpiration to soil water deficit (Soltani et al., 2000), for response to photoperiod (Soltani et al., 2004a), for harvest index (Soltani et al., 2005), for phenological development (Soltani et al., 2006c), and for nitrogen accumulation and partitioning (Soltani et al., 2006b). This model has been used for some simulation studies/investigations (Gholipoor and Soltani, 2005a, b; 2006; Gholipoor et al., 2006a, b).

Briefly, in seedling emergence sub model of CYRUS, emergence response to temperature is described by a dent-like function with cardinal temperatures of 4.5 (base), 20.2 (lower optimum), 29.3 (upper optimum) and $40{ }^{\circ} \mathrm{C}$ (ceiling temperature). Six physiological days (i.e. number of days under optimum temperature conditions) (equivalent to thermal time of $94{ }^{\circ} \mathrm{C}$ days) are required from sowing to emergence at a sowing depth of $5 \mathrm{~cm}$. The physiological days requirement is increased by 0.9 days for each centimeter increase in sowing depth. Snow cover effect is considered on the basis of daily maximum and minimum temperatures, as presented in Ritchie (1991).

In leaf sub model, cardinal temperatures for nod appearance are $6.0^{\circ} \mathrm{C}$ for base, $22.2{ }^{\circ} \mathrm{C}$ for optimum and $31.0^{\circ} \mathrm{C}$ for ceiling temperature. Leaf senescence on the main stem starts when the main stem has about 12 nodes and proceeds at a rate of $1.67 \%$ per each day increase in physiological day (a day with non-limiting temperature and photoperiod). Leaf production per plant versus main stem node number occurs in two phases; phase 1 when plant leaf number increases with a slower and density-independent rate (three leaves per node), and phase 2 with a higher and density-dependent rate of leaf production (8-15 leaves per node).

Phenological development is calculated using multiplicative model that include a dent-like function for response to temperature, and a quadratic function for response to photoperiod. Photoperiodsensitivity is considered to be different in various cultivars, and cardinal temperatures for phenological development are $0{ }^{\circ} \mathrm{C}$ for base, $21^{\circ} \mathrm{C}$ for lower optimum, $32{ }^{\circ} \mathrm{C}$ for upper optimum and $40{ }^{\circ} \mathrm{C}$ for ceiling temperature. The cultivars require 25-31 physiological days from $E$ to $R_{1}, 8-12$ from $R 1$ to $R 3,3-5$ from R3 to R5, 17-18 from R5 to R7, and 6 from R7 to R8 (See Soltani et al. (2006d)).

The biomass production is calculated based on extinction coefficient (KS) and radiation use efficiency (RUE). It assumes that KS is not radiation- and plant density-dependent. The RUE assumes to be constant $\left(1 \mathrm{~g} \mathrm{MJ}^{-1}\right)$ across plant densities, but not across temperatures. After correction of RUE for temperature, it is not affected by either solar radiation or vapor pressure deficit (VPD). The partitioning of biomass between leaves and stems is achieved in a biphasic pattern before first-seed stage. After this stage, the fixed partitioning coefficients are used for calculating biomass allocation. 
Despite of many simulation models in which the linearity of harvest index increases has been used as a simple means to analyze and predict crop yield in experimental and simulation studies (see Soltani et al. (2005) and related references for more detail), the CYRUS model assumes that its increase is biphasic with turning point temperature equal to $17^{\circ} \mathrm{C}$. The similar approach has been proved to be appropriate for application in wheat (Soltani et al., 2004b).

The relation between total $\mathrm{N}$ and total biomass throughout the growth period is based on nonlinear segmented model (with two segments/phases). Therefore, the rates of $\mathrm{N}$ accumulation during phase 1 and 2 are different, and the turning point between two phases of $\mathrm{N}$ accumulation is considered $218.3 \mathrm{~g}$ biomass per $\mathrm{m}^{2}$. The distribution of $\mathrm{N}$ to different parts of plant is calculated using appropriate functions and coefficients.

In soil water balance sub model, daily soil water content is estimated as fraction transpirable soil water (FTSW, which ranges from 0 to 1 ) to calculate the degree of water limitation experienced by the crop. Similar to that described by Amir and Sinclair (1991), it accounted for additions from infiltration, and losses from soil evaporation, transpiration and drainage. Infiltration is calculated from daily rainfall less any run-off. Run-off is estimated using the curve number technique (Knisel, 1980). Soil evaporation (Ev.) is calculated using the two-stage model as implemented in spring wheat model developed by Amir and Sinclair (1991). Stage I Ev. occurs when water present in the top $200 \mathrm{~mm}$ of soil, and FTSW for the total profile is greater than 0.5. Stage II Ev. occurs when the water in the top layer is exhausted or the FTSW for the total soil profile reaches to less than 0.5. In stage II, Ev. is decreased substantially as a function of the square root of time since the start of stage II. The calculation of Ev. is returned to stage I only when rain or irrigation of greater than $10 \mathrm{~mm}$ occurs. Like procedure of Tanner and Sinclair (1983) and Sinclair (1994), the daily transpiration rate is calculated directly from the daily rate of biomass production, transpiration efficiency coefficient (=5 Pa) and VPD. The calculation of VPD is based on suggestion of Tanner and Sinclair (1983) that it to be approximately 0.75 of the difference between saturated vapor pressure calculated from daily maximum and minimum temperatures.

\section{RESULTS and DISCUSSION}

The rate of change in solar radiation within the 43 years in Gorgan, Iran presented in Table 1. As it can be seen, the changes for solar radiation $\left(\mathrm{MJm}^{-2} \mathrm{~d}^{-1} \mathrm{year}^{-1}\right)$ were negatively significant in December, but negligible in other months. The report of Stanhill and Moreshet (1992) for the years 1958 to 1985 indicates a statistically significant worldwide decrease of global solar radiation averaging 5.3\% especially in north hemisphere. Similar results have been also reported for the western as well as eastern sections of the former Soviet Union (Abakumova et al., 1996). The natural and anthropogenic aerosols absorb solar 
radiation, and this solar absorption within the atmosphere, together with the reflection of solar radiation to space, leads to a reduction in the solar radiation absorbed by the Earth's surface.

Although the changes in maximum temperature were not significant, but the trend was in increasing manner for February, March, April, August, September and October. Lu et al. (2006) and Fiscus et al. (1997) found the warming trend for the named temperature, and demonstrated that, this can affect productivity of crops. The upwardly changes of minimum temperature appeared to be significant only for May $\left(1.45{ }^{\circ} \mathrm{C}\right.$ per 43 years $)$ and August $\left(1.48{ }^{\circ} \mathrm{C}\right.$ per 43 years $)$. Generally, reports indicating that globally averaged minimum temperatures continue to increase at a faster rate than the maximum temperatures, resulting in a narrowing of the diurnal temperature range (Karl et al., 1993; Vose et al., 2005). In Beiging, China it has been shown that the linear rate of increase in minimum temperature is 4.08 ${ }^{\circ} \mathrm{C} / 100$ year; whereas the maximum temperature increases with a linear rate of $2.45^{\circ} \mathrm{C} / 100$ years (Karl et al., 1993; Xie and Cao, 1996). Other reports for China indicating that in north regions, increasing trend of minimum temperature for period 1951-1990 has been more sensible, when compared to maximum temperature (Tao et al., 2003). Analyzing daily and monthly maximum and minimum surface air temperatures at 66 weather stations over the eastern and central Tibetan Plateau for temporal trends also confirmed the asymmetric pattern of greater warming trends in minimum temperature or nighttime temperatures as compared to the daytime temperatures (Lu et al., 2006). In central Europe, despite of lowlying stations for which the above named behavior has been found, data from mountain top stations show a similar increase for both minimum temperature and maximum temperature (Weber et al., 1994). In Iran, results regarding Kermanshah showed that except for January, February and March, the increase in minimum temperature is considerable for all other months, especially June (Gholipoor et al., 2006a); whereas maximum temperature appears to show increasing trend only for April, May, June and August; the increasing trend of temperature in Tabriz has tended to have asymmetric pattern too (Gholipoor, 2008). Asymmetric change has been also reported for many other regions/countries, including southeastern Europe (Brázdil et al., 1996), United States and Canada (Karl et al., 1984). There are a number of possible factors, such as an increase in cloud cover, contributing to decreases in the diurnal temperature range (Easterling et al., 1997; Lu et al., 2006).

It found an increasing trend for number of days with temperature greater than $35{ }^{\circ} \mathrm{C}$ in April and October, but statistically no change in other months (Table 1). The slope of this trend was more considerable for October as compared to April. The rate of change for number of days with temperature lower than $0{ }^{\circ} \mathrm{C}$, and for night and day temperatures was presented in Table 2. Number of days with temperature less than $0{ }^{\circ} \mathrm{C}$ tended to have no change across years 1961 to 2003 . The rate of upwardly changes in night temperature $\left({ }^{\circ} \mathrm{C}\right.$ year $\left.{ }^{-1}\right)$ was statistically considerable for May $\left(1.37{ }^{\circ} \mathrm{C}\right.$ per 43 years $)$ and 
August $\left(1.12{ }^{\circ} \mathrm{C}\right.$ per 43 years), but negligible for others. The probability level for changes in day temperature tended to be higher than 0.05 , suggesting no statistically changes in it.

The climate change has resulted in that the value of rainfall to be decreased only in March (Table 2); this is in agreement with Smith et al. (2000) who reported about $4.1 \mathrm{~mm}_{\text {year }}{ }^{-1}$ decrease in rainfall for years 1910 to 1995 . The rate of increase in number of days with rainfall, say wet and/or rainy days, appeared to be 0.0737 day year ${ }^{-1}$ for December, but statistically zero for other months (Table 3); this increase in rainy days is contrary to report of Zhai et al. (1999). As seen in this Table, there is similar situation for number of days with rainfall lower than and/or equal to $10 \mathrm{~mm}(\mathrm{R} \leq 10 \mathrm{~mm})$. Despite of these two variables, number of days with $10<R \leq 30$ appeared to show decreasing trend (March: 2.45 days per 43 years; October: 1.17; December: 1.35), and that of days with $\mathrm{R}>30$ showed no change (Table 3).

Across the period 1961 to 2003, the time from sowing to emergence was statistically the same for all treatment combinations (i.e. sowing date $\times$ cultivar) (Table 4). As it was presented in this Table, the time from emergence to flowering (R1) has considerably been decreased for cultivar Jam sown at day of year 70 (4.0506 days per 43 years); the advancing of flowering is in agreement with repots of the Menzel and Fabian (1999) and $\mathrm{Lu}$ et al. (2006) for other species; the change in length of this period was statistically negligible for other treatment combinations. The length of period between flowering and pod initiation (R3) appeared to show decreasing trend only for sowing at day of year 70 (cultivar Jam: 0.8213 day par 43 years; cultivar Arman: 1.6469 day par 43 years). The decreasing rate of time from pod initiation to pod filling (R5) was 0.0377 day per year (1.6211 day per 43 years) for cultivar Hashem sown at day of year 90, but statistically zero for other cultivars sown at this date and at other dates (Table 5). The length of period between pod filling and pod yellowing (R7) appeared to be the same across 43 years for all sowing dates and cultivars (Table 5). As it was shown in this Table, the decreasing trend regarding length of stage pod yellowing to stage physiological maturity (R8) appeared to be considerable for cultivar Beauvanij which seeded at day of year 70, but negligible for other treatment combinations. The climatechange-related advance in some phenophases of chickpea is in agreement with reports for other plants/crops (Fitter et al., 1995; Sparks et al., 2000; Lu et al., 2006). As it was speculated by Menzel and Fabian (1999) the decrease in length of phenophases, and consequently increasing the rest of growing season, may improve the opportunity for sowing the succession crop(s).

\section{CONCLUSION}

Generally, the result of this study revealed that the solar radiation has been decreased for month December. Although the value of maximum temperature appeared to be the same across years 1961 to 2003 for all months, that of minimum temperature tended to show increasing trend for May and August. The increase in number of days with temperature higher than $35{ }^{\circ} \mathrm{C}$ was considerable for April and 
October, but negligible for other months. The warming of night temperature was significant only for May and August. It found about $34 \mathrm{~mm}$ per 43 years decrease in monthly rainfall for March. The rate of increase in number of days with rainfall was 0.0737 day year ${ }^{-1}$ for December. Nearly similar situation was found for number of days with rainfall lower than and/or equal to $10 \mathrm{~mm}$. The change in number of days with rainfall higher than $10 \mathrm{~mm}$ and lower than and/or equal to $30 \mathrm{~mm}$ was in decreasing manner (March, October and December).

The length of time from sowing to emergence appeared to be constant across past years. The advance in flowering (R1) was true only for cultivar Jam seeded at day of year 70. The length of period from R1 to pod initiation (R3) has been diminished for sowing at day of year 70 (Jam and Arman). Only cultivar Hashem seeded at day of year 90 tended to have decreasing trend for length of period between R3 and pod filling. It found one day per 43 years decrease from pod yellowing to maturity for cultivar Beauvanij seeded at day of year 70 .

Because of highly difference between months for climate change, the difference between sowing dates for climate-related hastening in chickpea phenophases appeared to be considerable. Based on this finding, and on the fact that future climate change is predicted using past changes, it seems that the adaptation strategies for future, including agronomy and/or breeding programs, may be not the same for different sowing dates of chickpea.

\section{REFERENCES}

Abakumova, G.M., E.M. Feigelson and V. Russak et al., 1996. Evaluation of long-term changes in radiation, cloudiness, and surface temperature on the territory of the former Soviet Union. J. Climate, 9 (6): 1319-1327.

Amir, J. and T.R. Sinclair, 1991. A model of water limitation on spring wheat growth and yield. Field Crops Res., 29 (2-3): 59-69.

Brázdil, R., M. Budíková and I. Auer et al., 1996. Trends of maximum and minimum daily temperatures in central Europe. Int. J. Climatology, 16 (1): 765-782.

Curry, R.B., R.M. Peart and J.W. Jones et al., 1990. Response of crop yield to predicted changes in climate and atmospheric $\mathrm{CO}_{2}$ using simulation. Trans. ASAE., 33 (2): 1383-1390.

Cutforth, H.W., B. Woodvin and R.J. McConkey et al., 1999. Climate change in the semi arid prairie of southwestern Saskatchewan: Late winter-early spring. Can.J. plant Sci., 79 (3): 343-353.

Doorenbos, J. and W.O. Pruitt, 1977. Guidelines for Predicting Crop Water Requirements. Seconnd ed. (FAO Irrigigation and Drainage Paper 24). FAO, Rome (FAO Irrigigation and Drainage Paper 24). 
Dore, M.H.L. 2005. Climate change and changes in global precipitation patterns: What do we know? Environment International, 31 (8): 1167-1181.

Douglas, A.V. and P.J. Englehart, 1999. Inter-monthly variability of the Mexican summer monsoon. Proceedings of the Twenty-Second Annual Climate Diagnostics and Prediction. October 6-10, Washington, DC, U.S., pp. 246-249.

Easterling, D.R., B. Horton and P.D. Jones et al., 1997. Maximum and minimum temperature trends for the globe. Science, 277 (no. 5324): 364-367.

Fitter, A.H., R.S.R. Fitter and I.T.B. Harris et al., 1995. Relationships between first flowering date and temperature in the flora of a locality in central England. Funct. Ecol., 9 (1): 55-60.

Fiscus, E.L., C.D. Reid and J.E. Miller et al., 1997. Elevated $\mathrm{CO}_{2}$ reduces $\mathrm{O}_{3}$ flux and $\mathrm{O}_{3}$-induced yield losses in soybeans: Possible implications for elevated $\mathrm{CO}_{2}$ studies. J. Exp. Bot., 48 (no. 307): 307313.

Gholipoor, M. and A. Soltani, 2005a. Effect of past climate change on run-off in Gorgan. (Text in Persian). Proceedings of $5^{\text {th }}$ Iranian Hydrolic Conference, Nov. 8-10, Shahid Bahonar University of Kerman, Kerman, Iran.

Gholipoor, M. and A. Soltani, 2005b. Optimizing planting management in dormant sowing of chickpea using simulation. (Text in Persian, abstract in English). Proceedings of $1^{\text {st }}$ Iranian Pulse Symposium, Nov. 20-21, Ferdosi University of Mashhad, Mashhad, Iran.

Gholipoor, M. and A. Soltani, 2006. Comparing relative effects of temperature and photoperiod on development rate of chickpea, using simulation. (Abstract in persian). Proceedings of $9^{\text {th }}$ Iranian Crop Science Congress, Aug. 27-29, Aboureyhan Campus- University of Tehran, Tehran, Iran.

Gholipoor, M., A. Soltani and S. Sharafi, 2006a. Determining optimum sowing date for dormant seeding of chickpea in Kermanshah using simulation. (Abstract in persian). Proceedings of $9^{\text {th }}$ Iranian Crop Science Congress, Aug. 27-29, Aboureyhan Campus- University of Tehran, Iran.

Gholipoor, M., A. Soltani and F. Shekari et al., 2006b. Quantitative evaluation of climate change during past 44 years of Kermanshah and its effect on chickpea phenology, using simulation. (Abstract in persian). Proceedings of $9^{\text {th }}$ Iranian Crop Science Congress, Aug. 27-29, Aboureyhan CampusUniversity of Tehran, Tehran, Iran.

Gholipoor, M. 2008. Evaluating past surface air temperature change in Tabriz, Iran using hourly-based analyzing. Int. J. Agric. Res., 3 (2): 131-139.

Izaurralde, R.C., N.J. Rosenberg and R.A. Brown et al., 2003. Integrated assessment of Hadley Center (HadCM2) climate-change impacts on agricultural productivity and irrigation water supply in the conterminous United States Part II. Regional agricultural production in 2030 and 2095. Agric. For. Meteorol., 117 (1): 97-122. 
Karl, T.R., G. Kukla and J. Gavin, 1984. Decreasing diurnal temperature range in the United States and Canada from 1941 through 1980. J. Climate Appl. Met., 23 (11): 1489-1504.

Karl, T.R., P.D. Jones and R.W. Knight et al., 1993. A new perspective on recent global warming: Asymmetric trends of daily maximum and minimum temperature. Bulletin American Meteorol. Society, 74 (6): 1007-1023.

Kirschbaum, M.U.F. 2004. Direct and indirect climate-change effects on photosynthesis and transpiration. Plant Biol., 6 (3): 242-253.

Knisel, W.G. 1980. CREAMS: A Filed-scal Model for Chemicals, Runoff and Erosion from Agricultural Management Systems. Conservation Research Report 26, USDA, US. Gov. Print. Office, Washington, DC.

Lu, P., Q. Yu and J. Liu et al., 2006. Advance of tree-flowering dates in response to urban climate change. Agric. For. Meteorol., 138 (1-4): 120-131.

McInnes, K.L., R. Suppiah and P.H. Whetton et al., 2002. Climate Change in South Australia. CSIRO.

Menzel, A. and P. Fabian, 1999. Growing season extended in Europe. Nature, 397 (2): 659-663.

Olfert, O. and R.M. Weiss, 2006. Impact of climate change on potential distributions and relative abundances of Oulema melanopus, Meligethes viridescens and Ceutorhynchus obstrictus in Canada. Agriculture, Ecosystems and Environ., 113 (1-4): 295-301.

Pielke, R.A., D.S. Niyogi and T.N. Chase et al., 2002. A new focus on climate change and variability: a focus on India, invited paper to the advances in atmospheric and oceanic sciences. Proc. Indian Natl. Sci. Acad., 69 (3): 107-123.

Reddy, K.R., P.R. Doma and L.O. Mearns et al., 2002. Simulating the impacts of climate change on cotton production in the Mississippi Delta. Clim. Res., 22 (3): 271-281.

Ritchie, J.T. 1991. Wheat phasic development. In: Hanks, R.J. and J.T. Ritchie, (Eds.), Modeling Plant, Soil, Systems, Agronomy Monograph, No., 31, pp. 31-54.

SAS Institute, 1989. SAS/STAT User's Guide, Version 6, 4th ed. SAS Inst. Inc., Cary, NC.

Sinclair, T.R. 1994. Limits to Crop Yield. In: Boote, K.J., J.M. Bennet and T.R. Sinclair et al., (Eds.), Physiology and Determination of Crop Yield. ASA, CSSA, and SSSA, Madison, WI, pp. 509-532.

Smith, I.N., P. McIntosh and T.J. Ansell et al., 2000. South-west western Australia rainfall and its association with Indian Ocean climate variability. Int. J. Climatol., 20 (15): 1913-1930.

Soltani, A., K. Ghassemi-Golezani and F.R. Khooie et al., 1999. A simple model for chickpea growth and yield. Field Crops Res., 62 (2): 213-224.

Soltani, A., F.R. Khooie and K. Ghassemi-Golezani et al., 2000. Thresholds for chickpea leaf expansion and transpiration response to soil water deficit. Field Crops Res., 68 (3): 205-210. 
Soltani, A., B. Torabi and E. Zeinali et al., 2004a. Response of chickpea to photoperiod as a qualitative long-day plant. Asian J. Plant Sci., 3 (6): 705-708.

Soltani, A., S. Galeshi and M.R. Attarbashi et al., 2004b. Comparison of two methods for estimating parameters of harvest index increase during seed growth. Field Crops Res., 89 (2-3): 369-378.

Soltani, A., B. Torabi and H. Zarei, 2005. Modeling crop yield using a modified harvest index-based approach: Application in chickpea. Field Crops Res., 91 (2/3): 273-285.

Soltani, A., M.J. Robertson and A.M. Manschadi, 2006b. Modeling chickpea growth and development: Nitrogen accumulation and use. Field Crops Res., 99 (1): 24-34.

Soltani, A., G.L. Hammer and B. Torabi et al., 2006c. Modeling chickpea growth and development: Phenological development. Field Crops Res., 99 (1): 1-13.

Soltani, A., M.J. Robertson and Y. Mohammad-Nejad et al., 2006d. Modeling chickpea growth and development: Leaf production and senescence. Field Crops Res., 99 (1): 14-23.

Soltani, A., M.J. Robertson and B. Torabi et al., 2006e. Modelling seedling emergence in chickpea as influenced by temperature and sowing depth. Agric. For. Meteorol., 138 (1-4): 156-167.

Sparks, T.H., E.P. Jeffree and C.E. Jeffree, 2000. An examination of the relationship between flowering times and temperature at the national scale using long-term phenological records from the UK. Int. J. Biometeorol., 44 (2): 82-87.

Stanhill, G. and S. Moreshet, 1992. Global radiation climate changes: The World Network. Climate Change, 21 (1): 57-75.

Tanner, C.B., Sinclair, T.R., 1983. Efficient Water Use in Crop Production: Research or Re-search? In: Taylor, H.M., W.R. Jordan and T.R. Sinclair, (Eds.), Limitations to Efficient Water Use in Crop Production. ASA, CSSA, and SSSA, Madison, WI, pp. 1-27.

Tao, F., M. Yokozawa and Y. Hayashi et al., 2003. Future climate change, the agricultural water cycle, and agricultural production in China. Agriculture Ecosystems Environ., 95 (1): 203-215.

Vose, R.S., D.R. Easterling and B. Gleason, 2005. Maximum and minimum temperature trends for the globe: An update through 2004. Geophys. Res. Letts., 32: 23-30.

Weber, R.O., P. Talkner and G. Stefanicki, 1994. Asymmetric diurnal temperature change in the Alpine region. Geophysical Res. Letts., 21: 673-676.

Zhai, P.M., A. Sun and F.M. Ren et al., 1999. Changes of climate extremes in China. Clim. Change, 42 (1) : 203-218.

Xie, Z. and H.X. Cao, 1996. Asymmetric changes in maximum and minimum temperature in Beijing. Theoretical Appl. Clim., 55 (1-4): 151-156. 
Table 1. The rate of change (value of $b$ in equation $\mathrm{Y}=\mathrm{a}+\mathrm{bX})$ and its probability level $(P)$ for solar radiation $\left(\mathrm{MJm}^{-2} \mathrm{~d}^{-1}\right.$ year $\left.{ }^{-1}\right)$, maximum temperature $\left(\mathrm{T}_{\max } ;{ }^{\circ} \mathrm{C}\right.$ yea $\left.{ }^{-1}\right)$, minimum temperature $\left(\mathrm{T}_{\min } ;{ }^{\circ} \mathrm{C}\right.$ year $\left.^{-1}\right)$ and number of days with temperature greater than $35^{\circ} \mathrm{C}\left(\mathrm{T}>35\right.$; day year $\left.{ }^{-1}\right)$ during 1961-2003.

\begin{tabular}{lcccccccc}
\hline \multirow{2}{*}{ Month } & \multicolumn{2}{c}{ Solar radiation } & \multicolumn{2}{c}{$\mathrm{T}_{\max }$} & \multicolumn{2}{c}{$\mathrm{T}_{\min }$} & \multicolumn{2}{c}{$\mathrm{T}>35$} \\
\cline { 2 - 8 } & $\mathrm{B}$ & $P$ & $\mathrm{~b}$ & $P$ & $\mathrm{~b}$ & $P$ & $\mathrm{~b}$ & $P$ \\
\hline January & -0.0168 & 0.138 & -0.0004 & 0.991 & 0.0024 & 0.917 & ------ & ------ \\
February & -0.0155 & 0.198 & 0.0050 & 0.873 & -0.0100 & 0.658 & ------ & ------ \\
March & -0.0082 & 0.561 & 0.0028 & 0.922 & -0.0125 & 0.502 & ------ & ------ \\
April & -0.0233 & 0.270 & 0.0381 & 0.150 & 0.0079 & 0.672 & $\mathbf{0 . 0 1 1 5}$ & $\mathbf{0 . 0 1 1}$ \\
May & -0.0194 & 0.183 & -0.0232 & 0.323 & $\mathbf{0 . 0 3 3 8}$ & $\mathbf{0 . 0 3 3}$ & -0.0281 & 0.106 \\
June & 0.0083 & 0.612 & -0.0120 & 0.565 & 0.0012 & 0.926 & -0.0424 & 0.255 \\
July & -0.0261 & 0.178 & -0.0127 & 0.494 & 0.0204 & 0.068 & -0.0381 & 0.520 \\
August & -0.0037 & 0.774 & 0.0017 & 0.923 & $\mathbf{0 . 0 3 4 5}$ & $\mathbf{0 . 0 0 9}$ & 0.0252 & 0.666 \\
September & -0.0041 & 0.727 & 0.0110 & 0.541 & 0.0188 & 0.204 & 0.0205 & 0.268 \\
October & 0.0094 & 0.396 & 0.0297 & 0.189 & 0.0106 & 0.594 & $\mathbf{0 . 0 1 6 5}$ & $\mathbf{0 . 0 0 3}$ \\
November & -0.0101 & 0.342 & -0.0238 & 0.343 & 0.0043 & 0.823 & -0.0005 & 0.812 \\
December & $\mathbf{- 0 . 0 2 1 9}$ & $\mathbf{0 . 0 1 1}$ & -0.0248 & 0.301 & -0.0167 & 0.484 & ------- & ----- \\
\hline
\end{tabular}

The bold values are statistically significant.

Table 2. The rate of change (value of $\mathrm{b}$ in equation $\mathrm{Y}=\mathrm{a}+\mathrm{bX}$ ) and its probability level $(P)$ for number of days with temperature lower than $0{ }^{\circ} \mathrm{C}\left(\mathrm{T}<0\right.$; day year $\left.^{-1}\right)$, night temperature $\left({ }^{\circ} \mathrm{C}\right.$ year $\left.{ }^{-1}\right)$, day temperature $\left({ }^{\circ} \mathrm{C}\right.$ year $\left.^{-1}\right)$ and rainfall (mm year $\left.{ }^{-1}\right)$ during 1961-2003.

\begin{tabular}{lcccccccc}
\hline \multirow{2}{*}{ Month } & \multicolumn{2}{c}{$\mathrm{T}<0$} & \multicolumn{2}{c}{ Night $\mathrm{T}$} & \multicolumn{2}{c}{ Day T } & \multicolumn{2}{c}{ Rainfall } \\
\cline { 2 - 8 } & $\mathrm{b}$ & $P$ & $\mathrm{~b}$ & $P$ & $\mathrm{~b}$ & $P$ & $\mathrm{~b}$ & $P$ \\
\hline January & -0.0169 & 0.784 & 0.0016 & 0.948 & 0.0007 & 0.981 & -0.3379 & 0.302 \\
February & 0.0083 & 0.866 & -0.0063 & 0.790 & 0.0013 & 0.964 & -0.1033 & 0.733 \\
March & 0.0257 & 0.211 & -0.0081 & 0.683 & -0.0011 & 0.964 & $\mathbf{- 0 . 7 8 9 2}$ & $\mathbf{0 . 0 1 4}$ \\
April & ------ & ------ & 0.0162 & 0.404 & 0.0309 & 0.191 & -0.3563 & 0.250 \\
May & ----- & ------ & $\mathbf{0 . 0 3 1 9}$ & $\mathbf{0 . 0 5 0}$ & -0.0259 & 0.203 & -0.2561 & 0.530 \\
June & ------ & ------ & -0.0018 & 0.893 & -0.0082 & 0.648 & -0.2855 & 0.412 \\
July & ------ & ------ & 0.0120 & 0.312 & -0.0042 & 0.790 & -0.2619 & 0.320 \\
August & ------ & ------ & $\mathbf{0 . 0 2 6 0}$ & $\mathbf{0 . 0 4 2}$ & 0.0098 & 0.520 & -0.1022 & 0.733 \\
September & ------ & ------ & 0.0166 & 0.250 & 0.0135 & 0.403 & 0.1323 & 0.664 \\
October & ------ & ------ & 0.0157 & 0.425 & 0.0246 & 0.242 & -0.7885 & 0.063 \\
November & -0.0057 & 0.127 & -0.0020 & 0.917 & -0.0170 & 0.442 & 0.1945 & 0.694 \\
December & 0.0294 & 0.436 & -0.0182 & 0.428 & -0.0223 & 0.335 & -0.5896 & 0.084 \\
\hline
\end{tabular}

The bold values are statistically significant. 
Table 3. The rate of change (value of $\mathrm{b}$ in equation $\mathrm{Y}=\mathrm{a}+\mathrm{bX}$ ) and its probability level $(P)$ for number of days with rainfall (Wet days; day year ${ }^{-1}$ ), number of days with rainfall lower than and/or equal to 10 $\mathrm{mm}\left(\mathrm{R} \leq 10 \mathrm{~mm}\right.$; day year $\left.{ }^{-1}\right)$, number of days with rainfall greater than 10 and lower than and/or equal to $30 \mathrm{~mm}\left(10<\mathrm{R} \leq 30 \mathrm{~mm}\right.$; day year $\left.^{-1}\right)$ and number of days with rainfall greater than $30 \mathrm{~mm}(\mathrm{R}>30 \mathrm{~mm}$; day year $^{-1}$ ) during 1961-2003.

\begin{tabular}{lcccccccc}
\hline \multirow{2}{*}{ Month } & \multicolumn{2}{c}{ Wet days } & \multicolumn{2}{c}{$\mathrm{R} \leq 10 \mathrm{~mm}$} & \multicolumn{2}{c}{$10<\mathrm{R} \leq 30 \mathrm{~mm}$} & \multicolumn{2}{c}{$\mathrm{R}>30 \mathrm{~mm}$} \\
\cline { 2 - 9 } January & $\mathrm{b}$ & $P$ & $\mathrm{~b}$ & $P$ & $\mathrm{~b}$ & $P$ & $\mathrm{~b}$ & $P$ \\
February & 0.0039 & 0.927 & 0.0169 & 0.665 & -0.0151 & 0.337 & 0.0021 & 0.426 \\
March & 0.0104 & 0.785 & 0.0142 & 0.693 & -0.0047 & 0.774 & 0.0009 & 0.734 \\
April & -0.0071 & 0.863 & 0.0500 & 0.298 & $\mathbf{- 0 . 0 5 7 1}$ & $\mathbf{0 . 0 0 3}$ & 0.0000 & 1.000 \\
May & -0.0142 & 0.752 & -0.0088 & 0.839 & -0.0076 & 0.551 & 0.0021 & 0.602 \\
June & 0.0403 & 0.304 & 0.0405 & 0.234 & -0.0002 & 0.993 & 0.0000 & 1.000 \\
July & 0.0080 & 0.857 & 0.0044 & 0.918 & 0.0062 & 0.361 & -0.0026 & 0.659 \\
August & -0.0159 & 0.700 & -0.0020 & 0.958 & -0.0127 & 0.114 & -0.0012 & 0.742 \\
September & 0.0051 & 0.886 & 0.0039 & 0.903 & 0.0027 & 0.784 & -0.0015 & 0.731 \\
October & -0.0148 & 0.690 & -0.0308 & 0.387 & 0.0104 & 0.371 & 0.0056 & 0.253 \\
November & -0.0026 & 0.948 & 0.0343 & 0.298 & $\mathbf{- 0 . 0 2 7 2}$ & $\mathbf{0 . 0 5 0}$ & -0.0097 & 0.243 \\
December & 0.0455 & 0.251 & 0.0388 & 0.286 & 0.0023 & 0.886 & 0.0044 & 0.633 \\
\hline The & $\mathbf{0 . 0 7 3 7}$ & $\mathbf{0 . 0 4 5}$ & $\mathbf{0 . 1 1 0 8}$ & $\mathbf{0 . 0 0 5}$ & $\mathbf{- 0 . 0 3 1 4}$ & $\mathbf{0 . 0 4 1}$ & -0.0057 & 0.215 \\
\hline
\end{tabular}

The bold values are statistically significant.

Table 4. The rate of change (value of $\mathrm{b}$ in equation $\mathrm{Y}=\mathrm{a}+\mathrm{bX})$ and its probability level $(P)$ for periods from sowing to emergence (sowing-E; day year ${ }^{1}$ ), from emergence to flowering (E-R1; day year ${ }^{1}$ ) and from flowering to pod initiation (R1-R3; day year $^{1}$ ) for different cultivars and sowing dates during 1961-2003.

\begin{tabular}{clcccccc}
\hline \multirow{2}{*}{$\begin{array}{l}\text { Sowing date } \\
\text { (day of year) }\end{array}$} & \multirow{2}{*}{ Cultivar } & \multicolumn{2}{c}{ Sowing-E } & \multicolumn{2}{c}{ E-R1 } & \multicolumn{2}{c}{ R1-R3 } \\
\cline { 2 - 7 } 50 & Hashem & -0.0316 & 0.572 & 0.0787 & 0.392 & -0.0003 & 0.951 \\
& Jam & -0.0316 & 0.572 & 0.0735 & 0.415 & 0.0030 & 0.659 \\
& Beauvanij & -0.0316 & 0.572 & 0.0711 & 0.435 & 0.0020 & 0.757 \\
& Arman & -0.0316 & 0.572 & 0.0705 & 0.424 & 0.0032 & 0.551 \\
& & & & & & & \\
70 & Hashem & 0.0008 & 0.972 & -0.0575 & 0.363 & -0.0042 & 0.385 \\
& Jam & 0.0008 & 0.972 & $\mathbf{- 0 . 0 9 4 2}$ & $\mathbf{0 . 0 3 1 8}$ & $\mathbf{- 0 . 0 1 9 1}$ & $\mathbf{0 . 0 5 0}$ \\
& Beauvanij & 0.0008 & 0.972 & -0.0584 & 0.357 & -0.0015 & 0.809 \\
& Arman & 0.0008 & 0.972 & -0.0569 & 0.365 & $\mathbf{- 0 . 0 3 8 3}$ & $\mathbf{0 . 0 2 0}$ \\
& & & & & & & \\
90 & Hashem & 0.0038 & 0.785 & 0.0015 & 0.962 & -0.0051 & 0.174 \\
& Jam & 0.0038 & 0.785 & -0.0039 & 0.906 & -0.0005 & 0.918 \\
& Beauvanij & 0.0038 & 0.785 & 0.0008 & 0.982 & -0.0014 & 0.822 \\
& Arman & 0.0038 & 0.785 & 0.0035 & 0.910 & -0.0009 & 0.853 \\
\hline
\end{tabular}

The bold values are statistically significant. 
Table 5. The rate of change (value of $b$ in equation $\mathrm{Y}=\mathrm{a}+\mathrm{bX})$ and its probability level $(P)$ for periods from pod initiation to pod filling (R3-R5; day year ${ }^{1}$ ), from pod filling to pod yellowing (R5-R7; day year $^{1}$ ) and from pod yellowing to physiological maturity (R7-R8; day year ${ }^{1}$ ) for different cultivars and sowing dates during 1961-2003.

\begin{tabular}{|c|c|c|c|c|c|c|c|}
\hline \multirow{2}{*}{$\begin{array}{l}\text { Sowing date } \\
\text { (day of year) }\end{array}$} & \multirow{2}{*}{ Cultivar } & \multicolumn{2}{|c|}{ R3-R5 } & \multicolumn{2}{|c|}{ R5-R7 } & \multicolumn{2}{|c|}{ R7-R8 } \\
\hline & & $\mathrm{b}$ & $P$ & B & $P$ & $\mathrm{~b}$ & $P$ \\
\hline \multirow{4}{*}{50} & Hashem & -0.0045 & 0.395 & -0.0074 & 0.372 & 0.0080 & 0.642 \\
\hline & Jam & -0.0023 & 0.702 & 0.0038 & 0.570 & 0.0005 & 0.985 \\
\hline & Beauvanij & 0.0020 & 0.753 & 0.0002 & 0.984 & 0.0068 & 0.562 \\
\hline & Arman & -0.0029 & 0.478 & 0.0003 & 0.961 & 0.0063 & 0.641 \\
\hline \multirow{4}{*}{70} & Hashem & 0.0011 & 0.794 & 0.0041 & 0.513 & 0.0118 & 0.582 \\
\hline & Jam & -0.0062 & 0.302 & 0.0082 & 0.214 & -0.0039 & 0.845 \\
\hline & Beauvanij & 0.0033 & 0.587 & -0.0017 & 0.787 & -0.0234 & 0.0358 \\
\hline & Arman & -0.0060 & 0.192 & -0.0086 & 0.159 & 0.0051 & 0.775 \\
\hline \multirow{4}{*}{90} & Hashem & $-\mathbf{0 . 0 3 7 7}$ & 0.040 & -0.0023 & 0.717 & -0.0130 & 0.515 \\
\hline & Jam & 0.0085 & 0.171 & -0.0009 & 0.895 & -0.0124 & 0.466 \\
\hline & Beauvanij & 0.0030 & 0.616 & 0.0018 & 0.784 & -0.0069 & 0.647 \\
\hline & Arman & -0.0038 & 0.369 & 0.0030 & 0.628 & -0.0159 & 0.359 \\
\hline
\end{tabular}

The bold values are statistically significant. 